Article

\title{
An Adjustment Approach for Aerosol Optical Depth Inferred from CALIPSO
}

\author{
Zhaoliang Zeng, Zemin Wang and Baojun Zhang *(D)
}

check for updates

Citation: Zeng, Z.; Wang, Z.; Zhang, B. An Adjustment Approach for Aerosol Optical Depth Inferred from CALIPSO. Remote Sens. 2021, 13, 3085. https://doi.org/10.3390/rs13163085

Academic Editors: Muhammad Bilal and Janet E. Nichol

Received: 2 July 2021

Accepted: 4 August 2021

Published: 5 August 2021

Publisher's Note: MDPI stays neutral with regard to jurisdictional claims in published maps and institutional affiliations.

Copyright: (c) 2021 by the authors. Licensee MDPI, Basel, Switzerland. This article is an open access article distributed under the terms and conditions of the Creative Commons Attribution (CC BY) license (https:// creativecommons.org/licenses/by/ $4.0 /)$.
Chinese Antarctic Center of Surveying and Mapping, Wuhan University, Wuhan 430079, China; zhaoliang.zeng@whu.edu.cn (Z.Z.); zmwang@whu.edu.cn (Z.W.)

* Correspondence: bjzhang@whu.edu.cn

\begin{abstract}
The verification and correction of CALIPSO aerosol products is key to understanding the atmospheric environment and climate change. However, CALIPSO often cannot detect the full profile of aerosol for the low instrument sensitivity near the surface. Thus, a correction scheme for the aerosol extinction coefficient (AECs) in the planetary boundary layer (PBL) is proposed to improve the quality of the CALIPSO-based aerosol optical depth (AOD) at $532 \mathrm{~nm}$. This scheme assumed that the aerosol is vertically and uniformly distributed below the PBL, and that the AECs in the whole PBL are equal to those at the top of the PBL; then, the CALIPSO AOD was obtained by vertically integrating AECs throughout the whole atmosphere. Additionally, the CALIPSO AOD and corrected CALIPSO AOD were validated against seven ground-based sites across eastern China during 2007-2015. Our results show that the initial CALIPSO AOD obtained by cloud filtering was generally lower than that of the ground-based observations. After accounting for the AECs in the PBL, the adjustment method tended to improve the CALIPSO AOD data quality. The average $R$ (slope) value from all sites was improved by $7 \%(46 \%)$. Further, the relative distance between the ground track of CALIPSO and the ground station exhibited an influence on the validation result of CALIPSO AOD. The retrieval precision of CALIPSO AOD worsened with the increase in water vapor in the atmosphere. Our findings indicate that our scheme significantly improves the accuracy of CALIPSO AOD, which will help to provide alternative AOD products in the presence of severe atmospheric pollution.
\end{abstract}

Keywords: CALIPSO; aerosol optical depth; correction; planetary boundary layer

\section{Introduction}

Atmospheric aerosols, especially those in the planetary boundary layer (PBL), not only directly pose a threat to human health [1-3], they also play significant roles in weather and climate systems [4-8]. Meanwhile, numerous previous efforts have been devoted to precisely elucidating the spatial and temporal distribution of atmospheric aerosols from space-borne and ground-based measurements [9-11], as well as model simulations [12-14].

Compared to passive satellites, the Cloud-Aerosol Lidar and Infrared Pathfinder Satellite Observations (CALIPSO) is the most advanced satellite, which has an equatorial crossing time of 1330 local time (LT) and a 16-day revisit time [15]. As a space-based aerosol observation sensor, the Cloud-Aerosol Lidar with Orthogonal Polarization (CALIOP) on-board of the CALIPSO satellite, provides three-dimension distribution and properties of clouds (e.g., height, optical depth, phase, particle size) and aerosols (e.g., height, optical depth, and particulate extinction profile) $[15,16]$. CALIOP, with respect to passive ground-based instruments, e.g., the sun-photometer, can provide the atmospheric extinction profile, which allows the contribution to the total AOD of the PBL and the free troposphere to be separated. It is also can significantly minimize the uncertainties in estimating the climate forcing induced by the lack of vertical cloud and aerosol measurements [17]. Nevertheless, CALIPSO satellite had some uncertainties in instrument calibration biases, low signal-to-noise ratio (SNR), potentially erroneous assumptions of the 
aerosol extinction-to-backscatter ratio, misclassification of aerosol and cloud, etc. [10,18-21]; therefore, validation with other independent datasets is needed. Several studies have systematically assessed and improved the CALIPSO-based aerosols products over regional or even global scales [19,22-25]. For instance, Schuster et al. [26] pointed out that CALIPSO AOD data were better agreement with the AOD data obtained from the Aerosol Robotic Network (AERONET) after they excluded for dust samples. On the global scale, Omar et al. [27] assessed CALIPSO AOD accuracies using ground-based measurements from 2006 to 2010, and found that CALIPSO AODs were lower than AERONET AODs, especially for AERONET AOD < 0.1. Kim et al. [28] used AOD from the Moderate Resolution Imaging Spectroradiometer (MODIS) to evaluate CALIPSO, indicating that CALIPSO AOD is 63\% lower than MODIS AOD over the ocean from June 2006 to December 2010. To reduce the retrieval bias and uncertainties of CALIPSO AOD, Vaughan et al. [29] developed a new approach to determine the base altitudes of aerosol layers in the PBL, which serves as one part of CALIPSO's version 3 products. Oo and Holz [23] found that the integrated attenuated total color ratio could be used to constrain the selection of lidar ratio used in the CALIPSO AOD retrieval and improve the CALIPSO AOD.

Note that CALIOP may lose detection capability if the attenuated backscatter signal of aerosol is below $2 \sim 4 \times 10^{-4} \mathrm{~km}^{-1} \mathrm{sr}^{-1}$ [30]. In particular, the aerosol profile near the surface (below $1.5 \mathrm{~km}$ ) always has higher uncertainties [7] and may contribute more errors to CALIPSO AOD. In recent decades, China has undergone rapid economic growth with high aerosol concentrations significantly increased over China [31-35], especially in PBL, implying that all the aforementioned large uncertainties in PBL should be examined [16]. In addition, Schwartz et al. [36] pointed out that high-accuracy AOD observations would be very useful to improve aerosol data assimilation systems, implying that the correction of CALIPSO AOD in the PBL will help us to enhance the ability of aerosol data assimilation and its application in China [37].

Taking eastern China as a study area where the three largest economic areas are located as well as high emission zones, i.e., the Beijing-Tianjin-Hebei (BTH) region, the Yangtze River Delta (YRD) region, the Pearl River Delta (PRD) region, the aims of this work were to evaluate CALIPSO AOD products using ground-based AODs and to propose an adjustment approach to improve the CALIPSO AOD accuracy, which corrects for the attenuated extinction from CALIPSO in the PBL. This new product is termed CALIPSO AOD (corrected). Such a study will serve as the basis for polluted area, modeling aerosol, and aerosol-cloud interaction research in the eastern China. Additionally, this will help us understand the aerosol vertical distribution, the contribution of low-level aerosol in eastern China, and its coupling with the meteorological conditions. Here, we use two aerosol observation datasets from AERONET and the China Aerosol Remote Sensing Network (CARSNET) to verify the CALIPSO AOD and its corrected product. The datasets from the CALIPSO, AERONET, CARSNET, and the meteorological data are described in Section 2. Section 3 introduces the CALIPSO AOD retrieval, correction, matching and comparison methodology. Section 4 gives intercomparisons of the CALIPSO AOD, CALIPSO AOD (corrected), and ground-based AOD, and the effects of the relative humidity on the accuracies of CALIPSO AOD and CALIPSO AOD (corrected). Section 5 discusses the results, while Section 6 concludes this study with a summary.

\section{Datasets and Methods}

\subsection{CALIOP Data}

CALIOP is a three channel lidar, with detectors that collect $532 \mathrm{~nm}$ parallel, $532 \mathrm{~nm}$ perpendicular, and $1064 \mathrm{~nm}$ light that is backscattered from molecules and particulates in the atmosphere [38]. CALIOP Level 2 (L2) products include Profile product, Layer product, and Vertical Feature Mask (VFM) product. Profile products mainly provide 532 and $1064 \mathrm{~nm}$ column AOD, the vertical distribution of the extinction coefficient, the backscatter coefficient, and the depolarization ratio. CALIOP provides a high horizontally resolution of $333 \mathrm{~m}$ (vertically resolution of $30 \mathrm{~m}$ ) for altitudes of $0-8.2 \mathrm{~km}, 1.0 \mathrm{~km}(60 \mathrm{~m})$ 
for altitudes of $8.2-20.2 \mathrm{~km}$, and $1.67 \mathrm{~km}(180 \mathrm{~m})$ for altitudes of 20.2-30.1 km (https: / / www-calipso.larc.nasa.gov/products/, last access: 31 June 2021) [38]. A more detailed description of the CALIPSO satellite and its parameters are also available on the NASA website (https: / / www-calipso.larc.nasa.gov / documents/, last access: 31 June 2021). Here, Level 2 (L2) products of CALIOP's version 3 during the daytime were used from 2007 to 2015 in the present study.

\subsection{Ground-Based AOD Data}

AERONET is a ground-based aerosol remote sensing network built by NASA and CNRS (Centre National de la Recherche Scientifique). The whole network is uniformly equipped with the multi-band sun-photometer of CIMEL (Cimel Electronique Company, Paris, France), which can automatically measure solar irradiance (direct solar radiation channel) and sky radiance (sky scattering channel) and realize automatic data transmission [39]. The aerosol optical parameters provided by this network can be used to study the global aerosol transport and radiation effect and verify the radiative transfer model and the accuracy of aerosol parameter inversions from the satellite [39]. AERONET contains AOD data of three quality levels: Level 1.0 (without strict cloud filtering and final verification); Level 1.5 (strict cloud filtering but no final verification, which was used in this study); Level 2.0 (quality guaranteed after strict cloud filtering and final verification) $[39,40]$.

CARSNET, which is similar to AERONET and has 50 sites across China, is a groundbased aerosol observation network set up by the China Meteorological Administration. The network also uses a CE-318 sun-photometer to observe aerosol parameters. CE-318 measures direct solar radiation to retrieve AOD and column precipitable water vapor [39]; its sky scanning data can be analyzed to retrieve aerosol particle size spectrum and aerosol phase function. The refractive index and single scattering albedo of aerosols can also be calculated [41]. In general, CARSNET AOD measurements across China are approximately $0.03,0.01,0.01$, and 0.01 larger than the measurements by AERONET in the 1020, 870, 670, and $440 \mathrm{~nm}$ channels, respectively [40]. The differences between the AOD data measured by non-calibrated instruments and those measured by reference instruments range from $4.5 \%$ to $15.3 \%$. However, after calibrating with a standard sensor, the difference of daily average AOD is less than $1.5 \%$ compared with the observed result of a standard instrument [40]. Therefore, five AERONET sites and two CARSNET quality-controlled sites (both named ground-based sites) were selected in eastern China (see Figure 1), which were used to validate the accuracy of CALIPSO-AOD and corrected CALIPSO-AOD.

\subsection{Meteorological Observation}

As satellite inversions of aerosol parameters, such as the extinction coefficient, are often affected by relative humidity (RH) and other meteorological conditions [42-44], we selected the corresponding relative humidity data to illustrate their influences on the aerosol extinction coefficient, and CALIPSO AOD inversion and correction. Other meteorological variables (e.g., annual average SP, Tem, RH, WS, and AOD) were used to describe the climate characteristics of the study sites. To match the passing time of the CALIPSO satellite around $1330 \mathrm{BJT}$, ground-based RH data at 1400 BJT from 2007 to 2015 were chosen, which were provided by the National Meteorological Information Center of China Meteorological Administration. A detailed statistical analysis of the climate characteristics of all sites is shown in Table A1. The land types for all sites are shown in Table 1. 


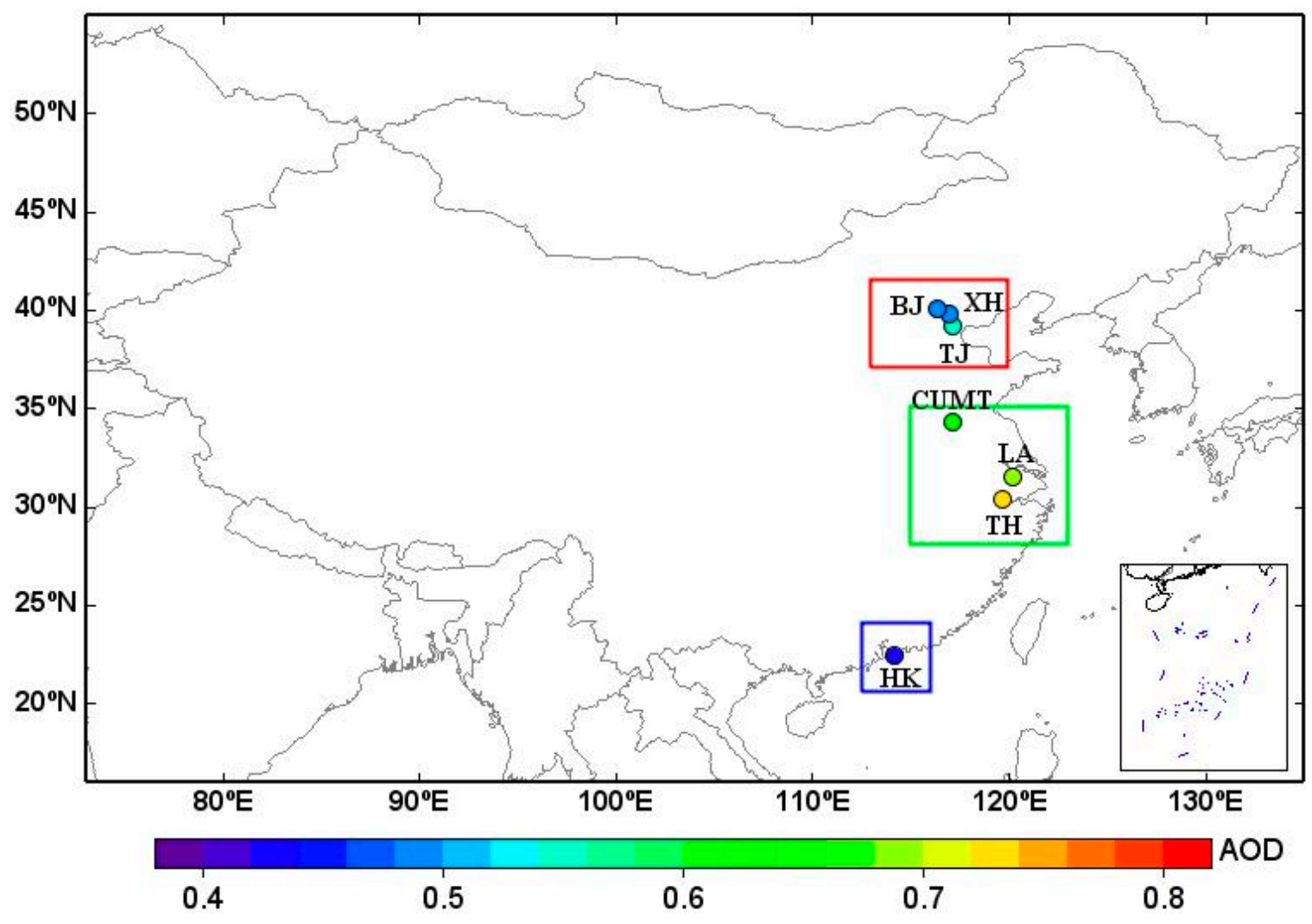

Figure 1. The geophysical distribution of AERONET sites (Hong_Kong_PolyU (HK), Beijing (BJ), Xianghe (XH), XuzhouCUMT (CUMT) and Taihu (TH) and CARSNET sites (Lin'an (LA) and Tianjin (TJ)) in China. The respective fill colors of the circles at the site locations represent the corresponding annual mean AOD values during the selected years. The Beijing-Tianjin-Hebei (BTH) region (red solid box), the Yangtze River Delta (YRD) region (green solid box), and the Pearl River Delta (PRD) region (blue solid box) are also shown.

Table 1. Statistics on the selected AERONET and CARSNET sites, including latitude, longitude, site type, and time period. The position relationship of AERONET sites and CARSNET sites relative to CALIPSO ground tracks, and three scenario types.

\begin{tabular}{|c|c|c|c|c|c|c|c|c|c|c|}
\hline Station/Region & $\begin{array}{l}\text { Lat. } \\
\left({ }^{\circ}\right)\end{array}$ & $\begin{array}{l}\text { Lon. } \\
\left({ }^{\circ}\right)\end{array}$ & $\begin{array}{l}\text { Alt. } \\
\text { (m) }\end{array}$ & Site Type & Time Period & $\begin{array}{c}\text { Min } \\
\text { Distance } \\
(\mathbf{k m})\end{array}$ & $\begin{array}{c}\text { Crossing } \\
\text { Time } \\
\text { (UTC) }\end{array}$ & $\begin{array}{l}\text { CALIPSO } \\
\text { Orbits }\end{array}$ & $\begin{array}{l}\text { Matched } \\
\text { Samples }\end{array}$ & $\begin{array}{c}\text { Scenario } \\
\text { Types }\end{array}$ \\
\hline Lin'an (LA)*/YRD & 30.30 & 119.73 & 138.6 & Forest & 2007,2010 & 4 & $5: 26$ & 43 & 6 & 2 \\
\hline Tianjin (TJ) */BTH & 39.10 & 117.17 & 3.3 & Urban & 2010 & 5 & $5: 30$ & 21 & 10 & 2 \\
\hline $\begin{array}{l}\text { Hong_Kong_PolyU } \\
\text { (HK)/PRD }\end{array}$ & 22.30 & 114.18 & 30.0 & Urban & 2007.01-2014.01 & 23 & $\sim 5: 55$ & 153 & 27 & 2 \\
\hline Xianghe $(\mathrm{XH}) / \mathrm{BTH}$ & 39.75 & 116.96 & 36.0 & Urban & 2007.01-2015.06 & 3 & $\sim 5: 30$ & 173 & 63 & 2 \\
\hline $\begin{array}{c}\text { Xuzhou-CUMT (CUMT) } \\
\text { /YRD }\end{array}$ & 34.22 & 117.14 & 59.0 & Urban & 2013.06-2015.12 & 6 & $\sim 5: 33$ & 49 & 11 & 2 \\
\hline Beijing (BJ)/BTH & 39.98 & 116.38 & 92.0 & Urban & 2007.01-2015.12 & 43 & $\sim 5: 29$ & 181 & 60 & 3 \\
\hline Taihu (TH) /YRD & 31.42 & 120.22 & 20.0 & Lake & 2007.01-2015.12 & 60 or 70 & $\begin{array}{l}\sim 5: 20 \text { or } \\
\sim 5: 27\end{array}$ & 232 & 31 & 1 \\
\hline
\end{tabular}

* Indicates the CARSNET sites. BTH: The Beijing-Tianjin-Hebei region; YRD: The Yangtze River Delta region; PRD: The Pearl River Delta region. Two CALIPSO satellite trajectories were within this circle were defined as scenario 1; one CALIPSO satellite trajectory was within this circle, but the shortest distance to ground-based sites less than $37.5 \mathrm{~km}$ were defined as scenario 2; and one CALIPSO satellite trajectory was within this circle, but the shortest distance to ground-based sites more than $37.5 \mathrm{~km}$ were defined as scenario 3 .

\section{Retrieval of CALIPSO AOD}

Figure 2 shows the flow chart of CALIPSO AOD inversion and correction. First, the aerosol extinction coefficients were obtained from CALIPSO L2 data (which underwent data preprocessing and cloud filtering), and then these were used to retrieve the CALIPSO AOD by using vertical integration. Moreover, the CALIPSO AOD (corrected) can be derived by using the vertical correction scheme and integration of the aerosol extinction 
coefficient profile within the atmospheric boundary layer. Finally, both the CALIPSO AOD and CALIPSO AOD (corrected) accuracies were verified by ground-based AOD. The detailed process steps are as follows.

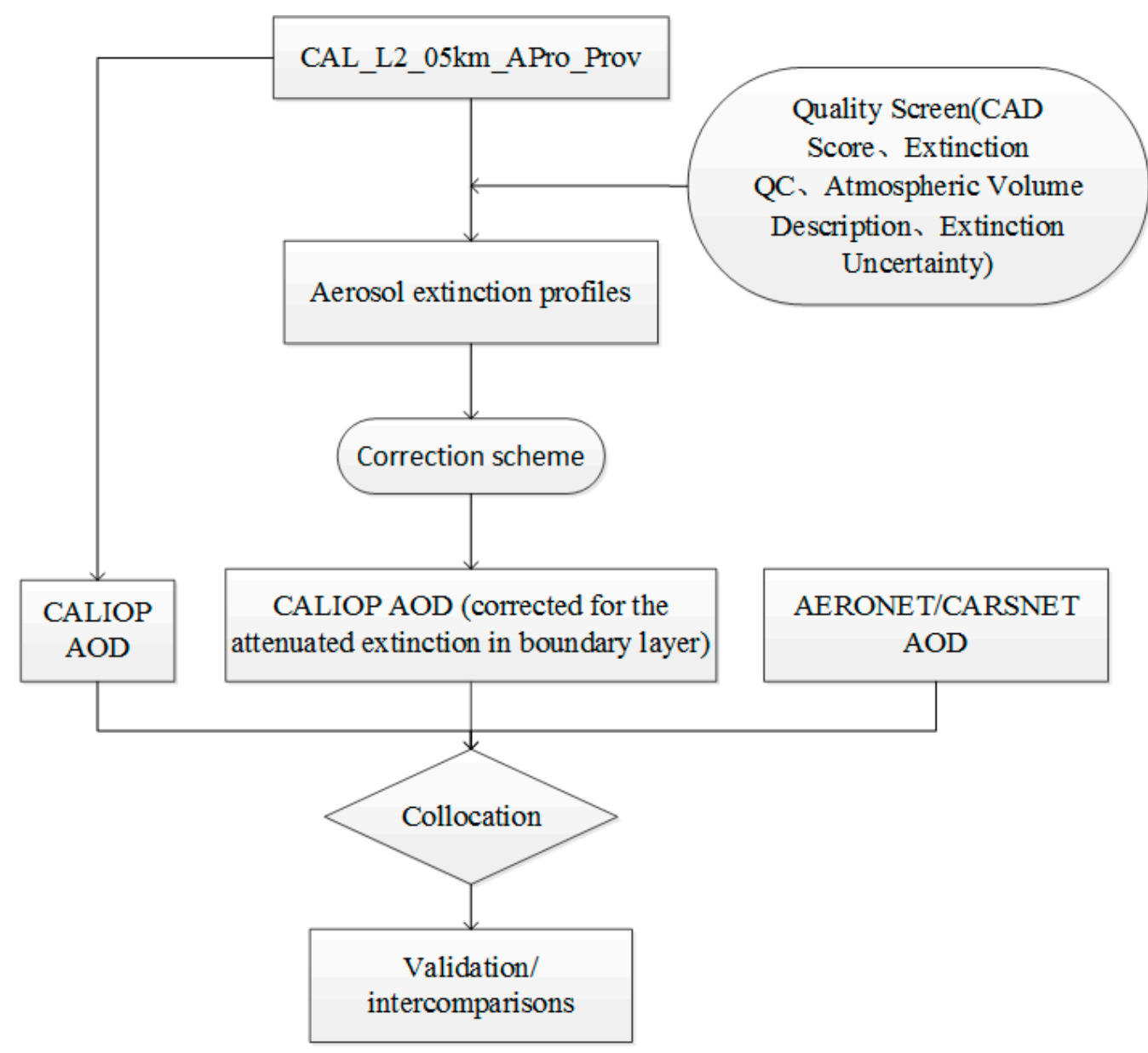

Figure 2. The flow chart of CALIPSO AOD retrieval, CALIPSO AOD retrieval corrected for the aerosol extinction coefficient in atmospheric boundary layer (CALIPSO AOD), and intercomparison analyses between both CALIPSO AOD retrievals and AERONET/CARSNET AOD measurements.

\subsection{CALIPSO AOD Retrieval and Quality Control}

The uncertainties in the inversion process of the atmospheric extinction coefficients mainly come from the distinction between cloud and aerosol, and the identification of aerosol type, etc. [45,46]; these should be addressed with the following steps: Extinction_Coefficient_532_Uncertainty $<99.9$ was set to indicate less uncertainty in the obtained data. The atmospheric volume description (AVD) parameter included the category information of the characteristic layer in the product data (cloud, aerosol and no signal) and the confidence level of the discriminant condition. The 1-3 bit value of AVD was set to 3 for identifying the samples that contained aerosol information. Selecting CAD_SCORE below -70 was to ensure that aerosol confidence was high enough. In addition, when the 1-3 bit of AVD in a single profile is 2, the profile should be removed to ensure that the retrieved AOD is not contaminated by clouds $[18,20,47,48]$. More details on quality control can be found in the works of $[15,49]$. After the above data processing, the high-quality aerosol extinction coefficient data can be obtained to retrieve the CALIPSO AOD at any thick column by integrating the aerosol extinction coefficient profile in the vertical direction. When integrating, the ground height difference of the Digital Elevation Model (DEM) and the ground-based site should be within $100 \mathrm{~m}$, to ensure that the length of their integral path is the same. 


\subsection{CALIPSO AOD Correction}

Figure 3 shows a sketch of the revised aerosol extinction coefficients in the PBL. Note that aerosols in the PBL include anthropogenic activities and biomass burning, etc. Here, the black dots represent aerosol particles, and the red solid lines are aerosol extinction coefficient profiles detected and obtained by CALIOP; based on the red solid line, the red dashed lines are the revised aerosol extinction coefficient profiles. The aerosol extinction coefficient near the surface layer is likely to have a lot of uncertainty and even some inversion errors. Moreover, if the backscattering signal emitted CALIOP is lower than its detection sensitivity of the instrument, the CALIOP sensor will not be able to detect the aerosol below PBL, which is important for the retrieval of AOD, $\mathrm{PM}_{2.5}$, and data assimilation and simulation $[36,49,50]$. To address the aforementioned issues, in this study, we assume that the meteorological conditions were relatively stable and that a uniform vertically distribution of the aerosol extinction coefficient below PBL height (the detailed PBLH retrieval method from CALIPSO can be found in Zhang's work [51]). Therefore, we considered that the aerosol extinction coefficient below the top of the PBL was uniformly equal to the aerosol extinction coefficient value at the top of the PBL (see the dash red line).



Figure 3. Schematic diagram of CALIPSO AOD that corrected by the aerosol extinction coefficient in the atmospheric boundary layer. The red solid line denotes the aerosol extinction coefficient profile, and the red dashed line denotes the corrected aerosol extinction coefficient profile.

\subsection{Matching Method}

To estimate the AOD values at the $532 \mathrm{~nm}$ from CALIPSO, the ground-based AOD observation data of the two $440 \mathrm{~nm}$ and $870 \mathrm{~nm}$ bands from CE-318 sun-photometer were interpolated to match the value of the $532 \mathrm{~nm}$ band, then the parameter value of $\alpha, \beta$ was calculated by the Equation (1). Finally, the ground-based AOD values of the $532 \mathrm{~nm}$ band are obtained by Equation (2).

$$
\begin{gathered}
\alpha=-\frac{\ln \left[\frac{\tau_{a}\left(\lambda_{1}\right)}{\tau_{a}\left(\lambda_{2}\right)}\right]}{\ln \left(\frac{\lambda_{1}}{\lambda_{2}}\right)}, \beta=\frac{\tau_{a}\left(\lambda_{1}\right)}{\lambda_{1}-\alpha} \\
\tau_{a}(\lambda)=\beta \lambda^{-\alpha}
\end{gathered}
$$

where $\tau_{a}(\lambda)$ is the aerosol optical depths at wavelength $\lambda$ and $\alpha$ and $\beta$ are the dimensionless scattering Ångström exponent and conversion constant, respectively. 
CALIPSO passes over the ground stations at about 1330 local time, so the qualitycontrolled ground-based AOD during 1300-1400 local time were averaged to match the CALIPSO AODs. The sample statistics in this study indicate that the AOD values of most samples were below 1 . In addition, CALIOP can easily identify clouds as aerosols under thin-cloud conditions, which leads to larger AOD values $[27,52,53]$. Therefore, the samples with AOD $>1$, which were derived from CALIPSO, were also excluded in this study. Note that the transit track of the CALIPSO satellite is not fixed, and Zhang et al. [51] summarized that the location relationships between CALIPSO and the ground station can be classified into three scenarios in China. According to the above method, Figure 4 shows three scenarios of locations for AERONET sites and CARSNET sites relative to CALIPSO passing tracks. The hollow red dots represent ground observation stations based on CARSNET and AERONET, and the black lines represent CALIPSO satellite trajectories selected for comparative analysis. Two CALIPSO satellite trajectories were within this circle were defined as scenario 1 ; one CALIPSO satellite trajectory was within this circle, but the shortest distance to ground-based sites less than $37.5 \mathrm{~km}$ were defined as scenario 2; and one CALIPSO satellite trajectory was within this circle, but the shortest distance to ground-based sites more than $37.5 \mathrm{~km}$ were defined as scenario 3 . The solid circles show that $\mathrm{BJ}$ station belongs to type 3, TH station belongs to type 2, and other stations belong to type 1 . Spatially, we averaged the CALIPSO AODs (which fall into the circle) and match them with the ground station. Finally, the samples of the CALIPSO satellite matched with each ground station are also given in Table 1.

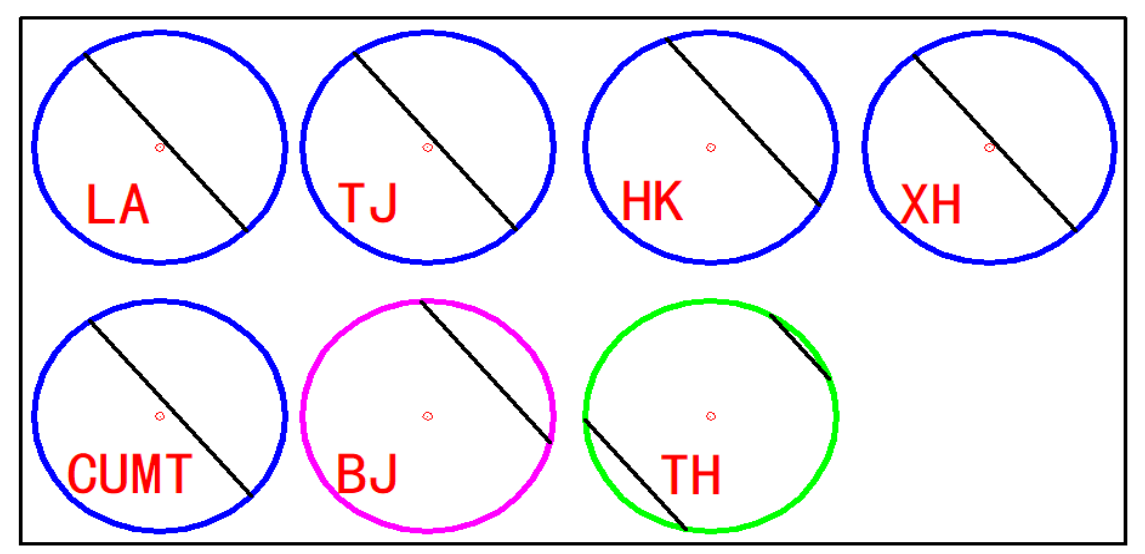

Figure 4. The spatial distribution of the locations of AOD sites relative to CALIPSO ground tracks over China. The black dots denote the ground-based CARSNET/AERONET AOD sites, and the black lines show CALIPSO ground tracks chosen for comparison analysis. The solid circles in blue, cyan and green correspond to scenario 2,3 , and 1 .

\section{Results}

\subsection{Intercomparisons of the CALIPSO AOD, CALIPSO AOD (Corrected) and Ground-Based AOD}

The intercomparison results between CALIPSO AOD and ground-based AOD at each site are show in Figure 5 and Table 2. It can be seen that the correlation coefficient $(R)$ values are $0.97,0.74,0.62,0.82,0.88,0.71$, and 0.35 over LA, TJ, HK, XH, CUMT, BJ, and $\mathrm{TH}$, respectively, with corresponding slopes of $0.67,0.7,0.34,0.68,0.46,0.64$, and 0.29 , and intercepts of $-0.03,0.01,0.16,0.02,0.14,0.03$, and 0.27 , respectively. The CALIPSO AOD at the TH site did not agree with the ground-based AOD values, and the $R$ value at this site was lower (failed the $95 \%$ confidence test). Note that TH station is located next to the wetland waters, with high relative humidity. Therefore, this weak correlation may be related to the impact of relative humidity on the lidar ratio of CALIPSO and sun-photometer observations. Moreover, we found that the multi-year average of AOD at the TH station from 2007 to 2015 was 0.74 , which is higher than that in any other site, suggesting that relative humidity probably effects on the ground-based AOD observation. In most sites of eastern China, the CALIPSO AOD retrieval exhibited good consistency with the ground- 
based AOD values, but the CALIPSO AOD values were obviously underestimated. This indicated that the CALIPSO AOD exhibited different error characteristics at the ground stations of eastern China $[53,54]$.
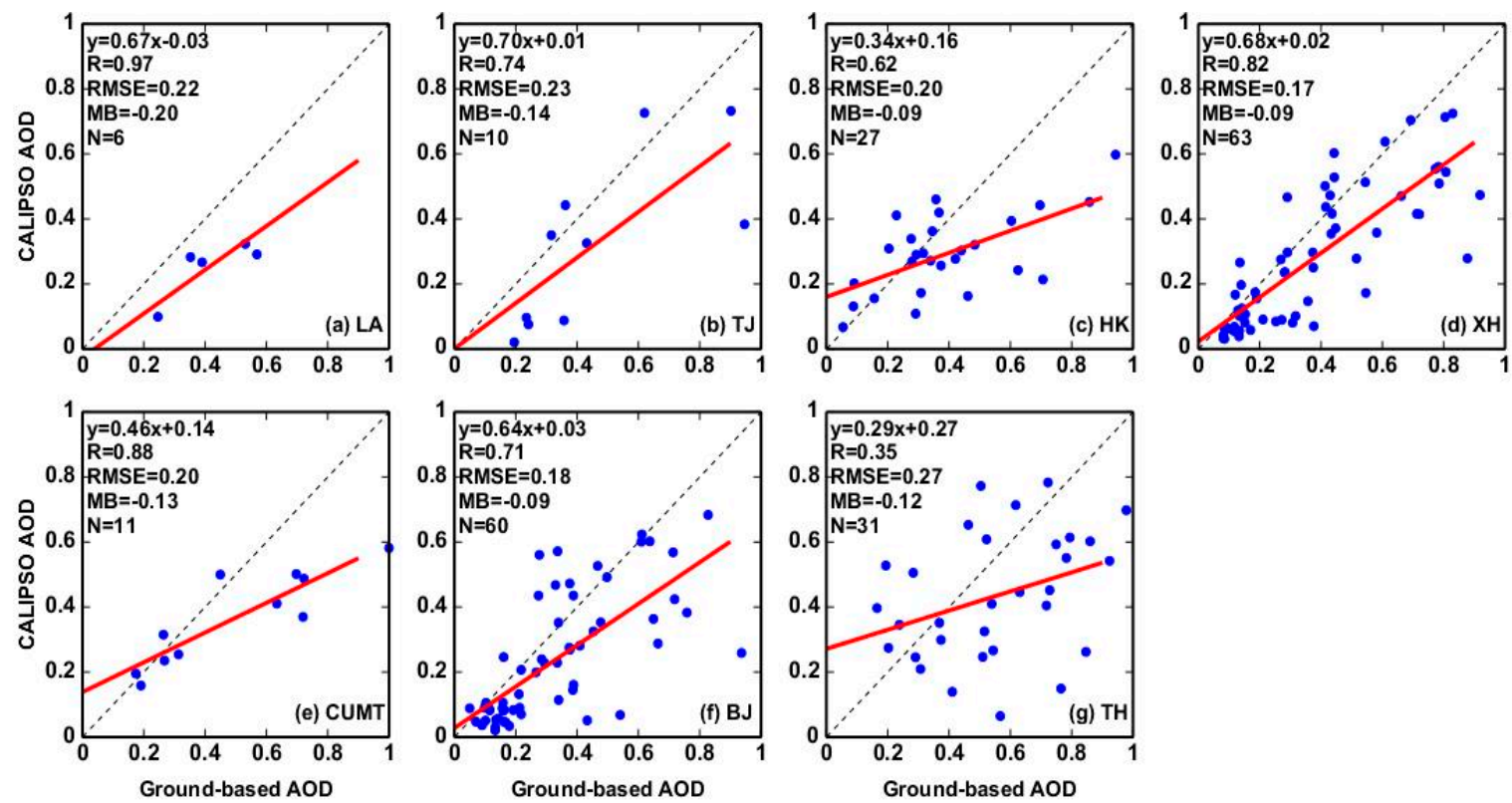

Figure 5. Comparison of $532 \mathrm{~nm}$ CALIPSO AOD and $532 \mathrm{~nm}$ ground-based AOD (CARSNET/AERONET) at the following sites: LA (a), TJ (b), HK (c), XH (d), CUMT (e), BJ (f), and TH (g). The red line is the linear fit as described by the correlation coefficients for the corresponding regression equation. The black dashed line represents 1:1 line, and RMSE denote root-mean-square error; MB denotes mean bias.

Table 2. The linear fitting results between CALIPSO AOD, CALIOPSO AOD (corrected), and ground-based AOD (CARSNET / AERONET) over China. The differences of linear fitting results between CALIPSO AOD and CALIOPSO AOD (corrected) are also listed.

\begin{tabular}{ccccccccc}
\hline \multirow{2}{*}{ Site } & \multicolumn{3}{c}{ CALIPSO AOD } & \multicolumn{2}{c}{ CALIPSO AOD (Corrected) } & \multicolumn{2}{c}{ Difference } \\
\cline { 2 - 9 } & Fitting Equation & $\boldsymbol{R}$ & $\mathbf{P}$ & Fitting Equation & $\boldsymbol{R}$ & $\mathbf{P}$ & Slope & $\boldsymbol{R}$ \\
\hline LA & $\mathrm{y}=0.67 \mathrm{x}-0.03$ & 0.97 & 0.00 & $\mathrm{y}=0.90 \mathrm{x}-0.01$ & 0.99 & 0.00 & 0.23 & 0.02 \\
TJ & $\mathrm{y}=0.70 \mathrm{x}+0.01$ & 0.74 & 0.04 & $\mathrm{y}=1.04 \mathrm{x}-0.03$ & 0.82 & 0.01 & 0.34 & 0.08 \\
HK & $\mathrm{y}=0.34 \mathrm{x}+0.16$ & 0.62 & 0.00 & $\mathrm{y}=0.75 \mathrm{x}+0.16$ & 0.66 & 0.00 & 0.41 & 0.04 \\
XH & $\mathrm{y}=0.68 \mathrm{x}+0.02$ & 0.82 & 0.00 & $\mathrm{y}=0.87 \mathrm{x}+0.06$ & 0.84 & 0.00 & 0.19 & 0.02 \\
CUMT & $\mathrm{y}=0.46 \mathrm{x}+0.14$ & 0.88 & 0.00 & $\mathrm{y}=0.71 \mathrm{x}+0.12$ & 0.95 & 0.00 & 0.25 & 0.07 \\
BJ & $\mathrm{y}=0.64 \mathrm{x}+0.03$ & 0.71 & 0.00 & $\mathrm{y}=0.82 \mathrm{x}+0.07$ & 0.73 & 0.00 & 0.18 & 0.02 \\
TH & $\mathrm{y}=0.29 \mathrm{x}+0.27$ & 0.35 & 0.06 & $\mathrm{y}=0.44 \mathrm{x}+0.31$ & 0.43 & 0.02 & 0.15 & 0.08 \\
\hline
\end{tabular}

The $\mathrm{R}$ values of CALIPSO AOD (corrected) and ground-based AOD are also shown in Figure 6 and Table 2, which are $0.99,0.82,0.66,0.84,0.95,0.73$, and 0.43 over LA, TJ, HK, XH, CUMT, BJ, and TH, respectively, and the corresponding slopes are $0.9,1.04,0.75,0.87,0.71$, 0.82 and 0.44 , respectively. The value of $R$ of the ground-based AOD and CALIPSO AOD (corrected) tended to increase after the aerosol extinction coefficient correction in PBL at the seven sites, relative to CALIPSO AOD, revealing that the CALIPSO AOD correction in PBL improves the CALIPSO AOD data quality. After correction, specifically, the $R$ (slope) values were increased from 0.97 to 0.99 (from 0.67 to 0.90 ), from 0.74 to 0.82 (from 0.70 to 1.04 ), from 0.62 to 0.66 (from 0.34 to 0.75 ), from 0.82 to 0.84 (from 0.68 to 0.87 ), from 0.88 to 0.95 (from 0.46 to 0.71 ), from 0.71 to 0.73 (from 0.64 to 0.82 ), and from 0.35 to 0.43 (from 0.29 to 0.44 ) at LA, TJ, HK, XH, CUMT, BJ, and TH, respectively. Note that the number of matched samples at LA (seven samples) was particularly small, but the correction effect was still 
good, and the corresponding $R$ and slope were enhanced by 0.02 and 0.23 , respectively (both at the $95 \%$ confidence level).
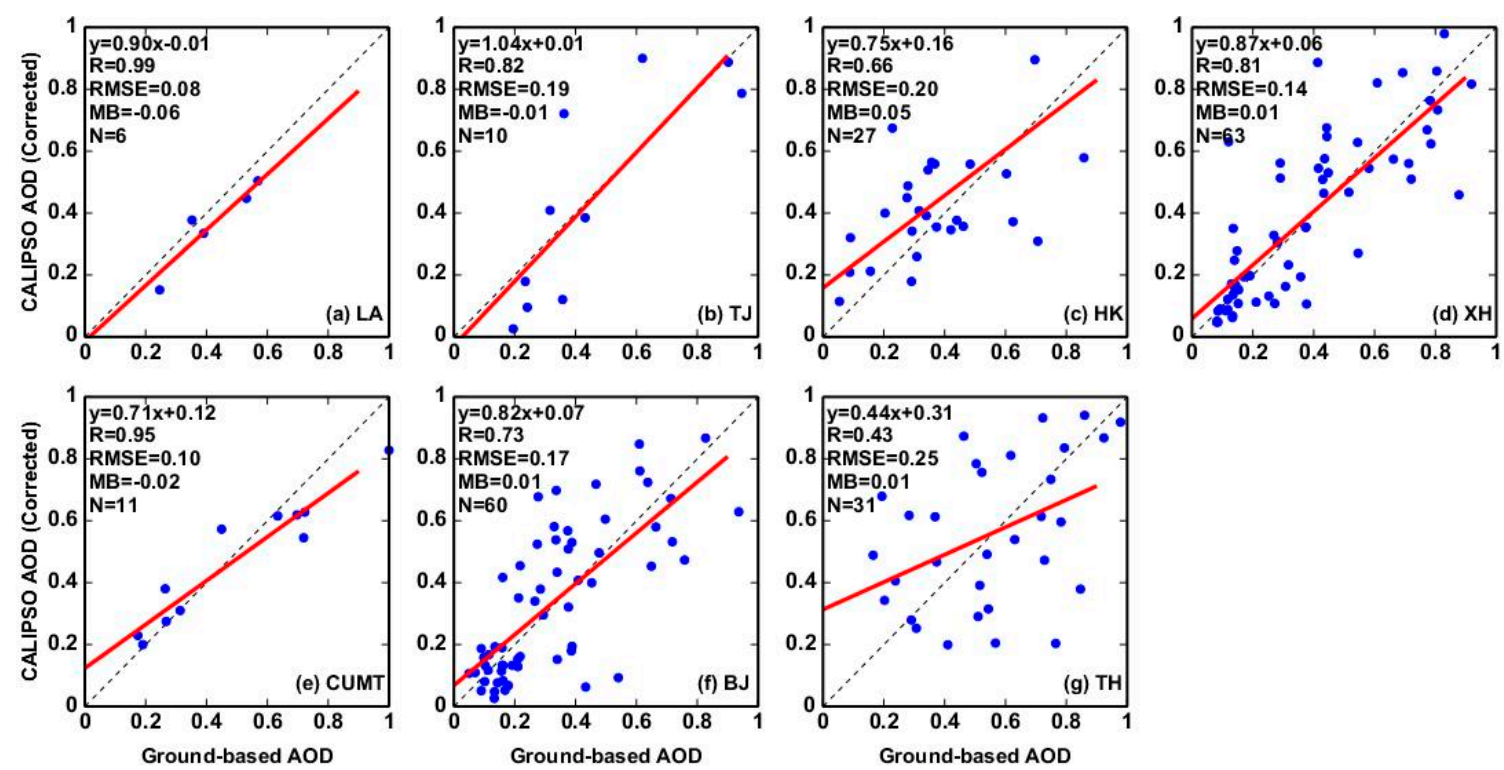

Figure 6. Same as Figure 5, but for CALIPSO AOD corrected by the aerosol extinction coefficient in the PBL.

\subsection{Error Analysis}

Figure 7 shows the scatter distribution of ground-based AOD, CALIPSO AOD and CALIPSO AOD (corrected) for three scenarios, indicating that the correlation between CALISPO AOD and CALIPSO AOD (corrected) was best for all three types (Table 3). The correlation between ground-based AOD and CALIPSO AOD (corrected)/CALIPSO AOD was the highest in scenario 2, followed by scenario 3 and scenario 1 . These results show that the closer the relative distance between the satellite orbit and the ground station is, the better the CALIPSO AOD validation is.

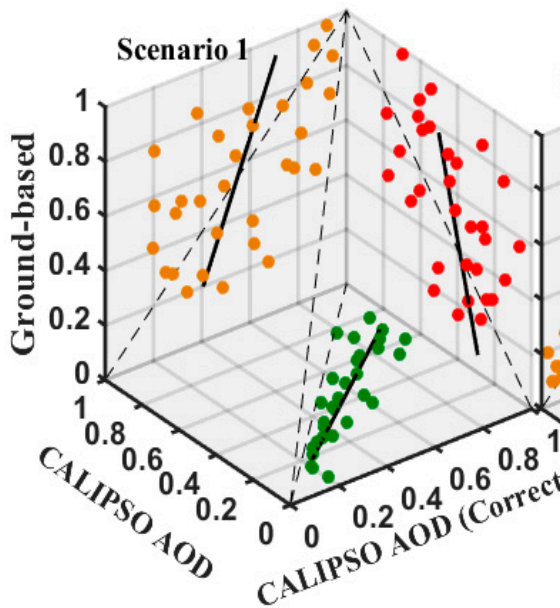

(a)

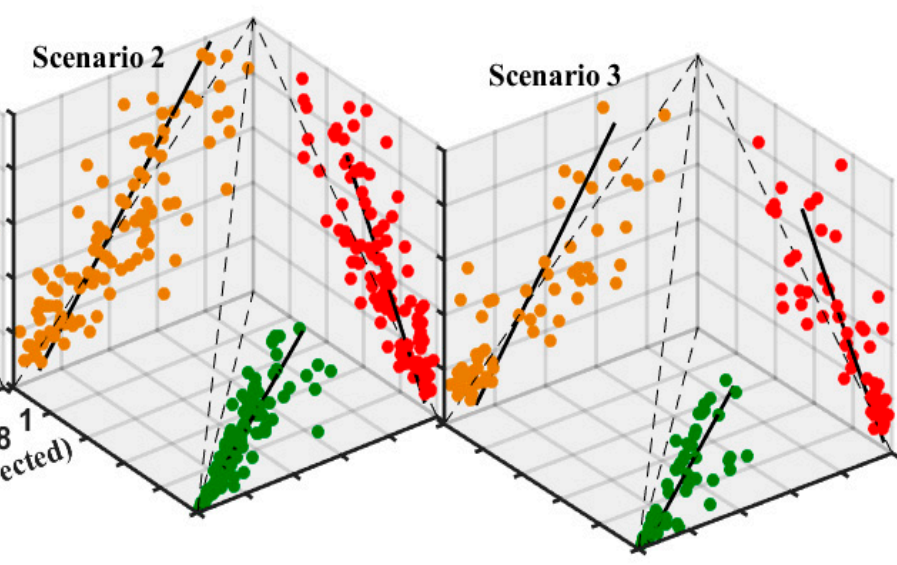

(b)

(c)

Figure 7. The scatterplots of CALIPSO AOD, CALIPSO AOD (corrected), and ground-based AOD at all sites for (a) scenario 1, (b) scenario 2, (c) scenario 3. The red dots, green dots and brown dots correspond to ground-based versus CALIPSO AOD, CALIPSO AOD versus CALIPSO AOD (corrected), and ground-based versus CALIPSO AOD (corrected).

For CALIPSO satellites, the AOD inversion results are not only affected by the CALIOP sensor signals (e.g., lidar ratio, measurement noise), but also by factors such as aerosolcloud classification, cloud, and water vapor. Relative humidity was chosen as one source of 
error on CALIPSO AOD inversion and correction under clear sky conditions $[38,43,55]$. The effect of relative humidity on the inferred aerosol extinction coefficient and AOD was studied $[42,56,57]$. We matched the RH data with the corresponding CALIPSO AOD at the same spatiotemporal scale. Moreover, the RH values were sorted in ascending order, and then the samples for the smallest (largest) one-third of total RH samples were classified as low (high) RH conditions, and the others as middle RH conditions. Figure 8 shows the relationship between CALIPSO AOD/CALIPSO AOD (corrected) and ground-based AOD under different $\mathrm{RH}$ conditions, all of which were higher under low $\mathrm{RH}(0.78 / 0.82)$ than under higher $\mathrm{RH}(0.56 / 0.62)$. This implies that an increase in water vapor in the atmosphere may change the optical thickness of the aerosol (the aerosol extinction coefficient increases with an increase in water vapor, which will affect the CALIPSO AOD value. Meanwhile, relative humidity will also naturally affect the AOD measured by ground-based sunphotometers.) and affect the correlation of AOD obtained by ground-based and satellite observation [58]. Similarly, compared with the CALIPSO AOD, the fitting regression of CALIPSO AOD (corrected) and ground-based AOD with higher correlation coefficients both under low and high RH conditions were clearly improved.

Table 3. Summary of the linear fitting between CALIPSO AOD, CALIPSO AOD (corrected) AOD and ground-based AOD (AERONET/CARSNET) at all the ground-based sites according to the three typical scenarios.

\begin{tabular}{ccccc}
\hline \multirow{2}{*}{ Scenario } & \multicolumn{2}{c}{\begin{tabular}{c} 
Ground-Based AOD vs. \\
\multicolumn{2}{c}{ Ground-Based AOD vs. } \\
\end{tabular}} & CALIPSO AOD & \multicolumn{2}{c}{ CALIPSO AOD (Corrected) } \\
\cline { 2 - 5 } & Slope & $\boldsymbol{R}$ & Slope & $\boldsymbol{R}$ \\
\hline 1 & 0.29 & 0.35 & 0.44 & 0.43 \\
2 & 0.75 & 0.76 & 0.97 & 0.77 \\
3 & 0.64 & 0.71 & 0.65 & 0.73 \\
\hline
\end{tabular}
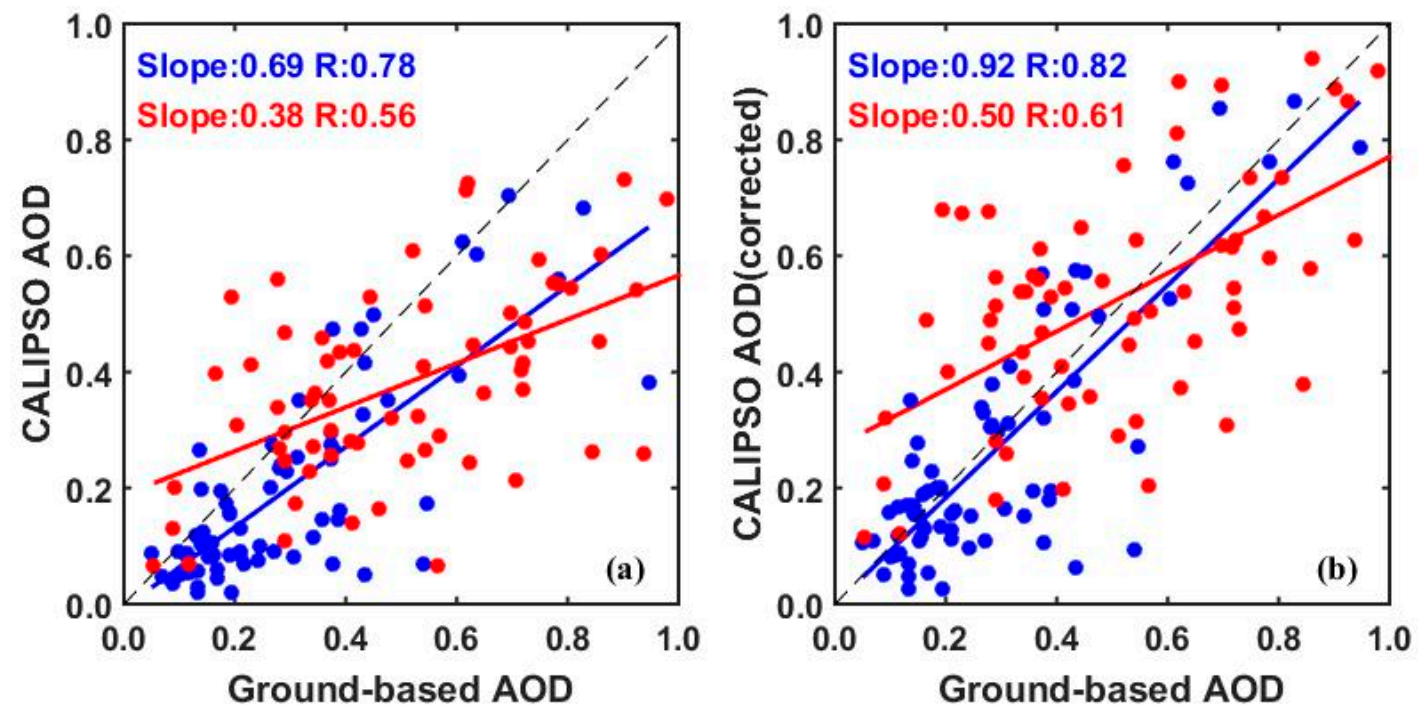

Figure 8. The values for the correlation between ground-based AOD and (a) CALIPSO AOD and (b) CALIPSO AOD (corrected) for different relative humidity at all stations, including the correlation coefficient and slope. Blue and red represent low relative humidity and high relative humidity conditions, respectively.

Although the accuracy of the cloud aerosol classification algorithm is obviously higher than that of the previous version [19], there are still some misjudgment cases for dust and smoke, such as the presence of thick dust which appears at high altitudes and is sometimes classified as cirrus cloud $[59,60]$. The existence of local cloud can also induce a difference in AOD between the CALIPSO and ground-based instruments (especially, 
when one detects cloud, while the another does not). For the ground-based AOD data, AERONET often cannot identify thin-layer cirrus cloud, which can cause AOD retrieval errors [61]. In addition, for band matching the ground data with the CALIPSO data, the quadratic polynomial fitting algorithm used to interpolate the AOD to wavelengths of $532 \mathrm{~nm}$ and $1064 \mathrm{~nm}$, and this interpolation step also may also introduce some errors during validation of the CALIPSO AOD. Moreover, in this study, due to the data available on the ground, the overpass period of the satellite, and the existence of cloud and other factors, the matched samples from ground data with CALIPSO data were few, which may also incur errors in validating the CALIPSO AOD. Note that many more CALIPSO AODs (corrected) are needed to further validate the accuracies, which can be used to monitor air quality in eastern China, especially in the regions of BTH, YRD, and PRD characterized by high emissions.

\section{Discussion}

To observe how the CALIPSO AOD performs under severely polluted conditions (especially when ground-based AOD values are more than 1), we also compared CALIPSO AOD with ground-based AOD at all sites (see Figure A1). The consistency of CALIPSO AOD and ground-based AOD was very poor, and the CALIPSO AOD values were generally less than 1 . This phenomenon is also consistent with the results of many previous studies [62-65]. On the one hand, compared with these studies based on the ground-based AOD, the mean $R$ of CALPSO AOD and CALPSO AOD (corrected) in our study reached as high as 0.72 and 0.77 , respectively, and the slope was closer to the line of $1: 1$. On the other hand, our CALIPSO AOD (corrected) perform better than CALIPSO AOD under severely polluted conditions. Overall, our results demonstrate the improved retrieved accuracy of our corrected method. Note that the AOD components near the surface layer are complex, and the concentration is high in the high-pollution areas [33,66,67]. Aerosol distribution at these heights can be obtained from ground-based lidar observations, which can be used to improve the accuracy of our correct method. However, ground-based lidar sites are few and unevenly distributed [68]. Therefore, we did not adjust the CALIPSO extinction coefficient with the ground-based lidar. However, in future work on CALIPSO AOD adjustments, we shall further improve the accuracy of the AOD data by collecting more profiles of the vertical distribution of aerosol extinction coefficients in different regions from ground lidar observations, and then compare and adjust the CALIPSO extinction coefficients.

\section{Conclusions}

A correction scheme for the aerosol extinction coefficient in the PBL was proposed to improve the accuracy of the CALIPSO AOD. The CALIPSO AOD (corrected) was validated with the ground-based measured data, and the possible error sources were analyzed. Overall, the initial CALIPSO AOD obtained by cloud filtering was generally lower than the ground-based observations. In contrast, after correcting for the aerosol extinction coefficient in PBL, the $R$ and slope values of the CALIPSO AOD (corrected) and ground-based AOD increased over all stations. Specifically, the $R$ (slope) values were increased from 0.97 to 0.99 (from 0.67 to 0.90 ), from 0.74 to 0.82 (from 0.70 to 1.04 ), from 0.62 to 0.66 (from 0.34 to 0.75 ), from 0.82 to 0.84 (from 0.68 to 0.87 ), from 0.88 to 0.95 (from 0.46 to 0.71 ), from 0.71 to 0.73 (from 0.64 to 0.82 ), and from 0.35 to 0.43 (from 0.29 to 0.44 ) at LA, TJ, HK, $\mathrm{XH}$, CUMT, BJ, and TH, respectively. It is revealing that the CALIPSO AOD adjustment method improved the CALIPSO AOD data quality. The correlation between ground-based AOD and CALIPSO AOD (corrected)/CALIPSO AOD was highest in type 2, followed by type 3 and type 1, indicating that the closer the distance between the satellite footprint and the ground station, the better validation of CALIPSO AOD. In addition, the inversion precision of AOD worsened with the increase in water vapor in the atmosphere as this may have caused a change in the extinction coefficient and optical thickness of aerosol and affected the retrieval of the AOD. In general, our approach improved the accuracy of the CALIPSO AOD, and will help to enhance the environmental-monitoring ability of CALIPSO [62]. The 
improved CALIPSO AOD can also be used to improve the assessment of aerosol radiative forcing and as an indicator to assess the effects of air quality on human health $[69,70]$.

Author Contributions: Conceptualization, B.Z.; methodology, Z.Z.; software, Z.Z.; validation, Z.Z. and B.Z.; formal analysis, Z.Z., B.Z. and Z.W.; writing—original draft preparation, Z.Z. and B.Z.; writing - review and editing, Z.Z., B.Z. and Z.W.; visualization, Z.Z. and B.Z.; funding acquisition, $Z$ ZW. All authors have read and agreed to the published version of the manuscript.

Funding: This work was supported by National Natural Science Foundation of China (Grant Nos. 41941010, 42006184 and 41776195).

Data Availability Statement: CALIPSO aerosol products are available at https:/ / subset.larc.nasa. gov/calipso / (last access: 31 June 2021). The CARSNET AOD and meteorological data used in the study can be obtained from the China Meteorological Data Service Center (CMDC, http:/ / data.cma. $\mathrm{cn} / \mathrm{en} /$, last access: 31 June 2021). AERONET AOD data are available at https:/ / aeronet.gsfc.nasa. gov / (last access: 31 June 2021).

Conflicts of Interest: The authors declare no conflict of interest.

\section{Appendix A}

Table A1. Descriptive statistics of meteorological variables at all sites.

\begin{tabular}{cccccccc}
\hline Station/Variable & LST & SP & RH & Tem & WS & Pre & AOD \\
\hline LA & 18.94 & 1002.44 & 73.80 & 16.48 & 2.18 & 4.49 & 0.60 \\
TJ & 14.98 & 1016.61 & 52.30 & 13.74 & 1.56 & 1.49 & 0.55 \\
HK & 25.70 & 1005.38 & 71.81 & 23.13 & 2.23 & 5.38 & 0.45 \\
XH & 14.32 & 1015.57 & 55.87 & 12.86 & 1.56 & 1.52 & 0.62 \\
CUMT & 15.81 & 1011.93 & 65.32 & 15.05 & 1.87 & 2.21 & 0.68 \\
BJ & 13.79 & 1011.05 & 56.03 & 12.84 & 1.74 & 1.76 & 0.62 \\
TH & 18.79 & 1016.24 & 70.91 & 16.84 & 2.44 & 3.56 & 0.74 \\
\hline
\end{tabular}

Table A2. Glossary.

\begin{tabular}{cc}
\hline Terminology & Definitions \\
\hline CALIPSO & Cloud-Aerosol Lidar and Infrared Pathfinder Satellite \\
AEC & Observations \\
PBL & Aerosol extinction coefficient \\
AOD & Planetary boundary layer \\
CALIOP & Aerosol optical depth \\
AERONET & Cloud-Aerosol Lidar with Orthogonal Polarization \\
CARSNET & Aerosol Robotic Network \\
BTH & China Aerosol Remote Sensing Network \\
YRD & Beijing-Tianjin-Hebei \\
PRD & Yangtze River Delta \\
VFM & Pearl River Delta \\
CIMEL & Vertical Feature Mask \\
RH & Cimel Electronique Company, France \\
AVD & Relative humidity \\
SNR & Atmospheric volume description \\
LST & Signal-to-noise ratio \\
SP & Land surface temperature \\
Tem & Surface press \\
WS & Temperature \\
Pre & Wind speed \\
\end{tabular}



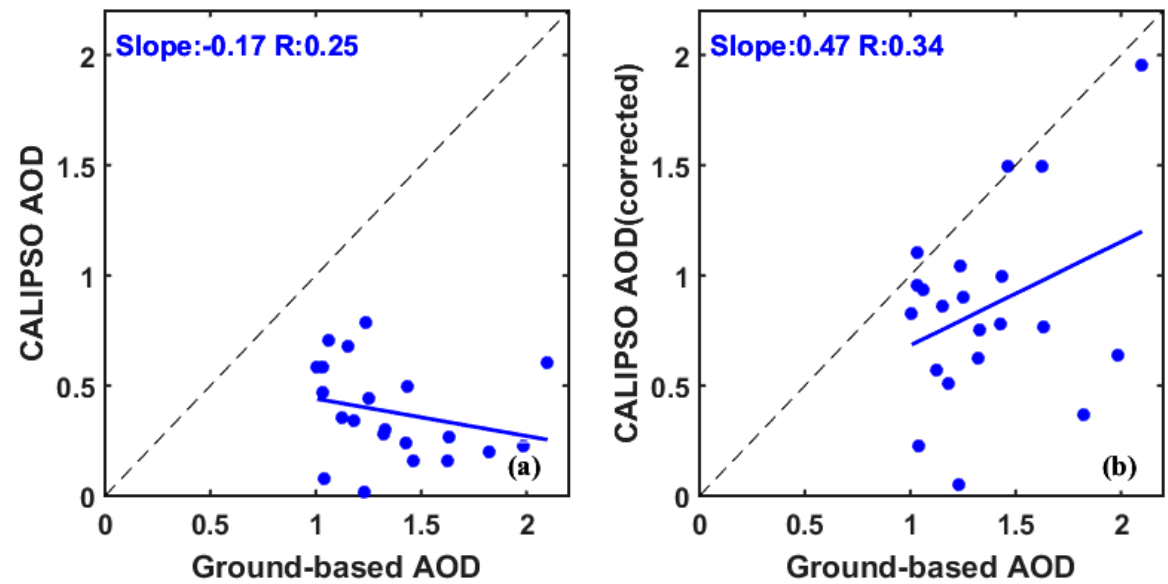

Figure A1. Comparison of (a) CALIPSO AOD, (b) CALIPSO AOD (corrected) and ground-based AOD at all sites, including correlation coefficient and slope.

\section{References}

1. Cohen, A.J.; Brauer, M.; Burnett, R.; Anderson, H.R.; Frostad, J.; Estep, K.; Balakrishnan, K.; Brunekreef, B.; Dandona, L.; Dandona, R.; et al. Estimates and 25-year trends of the global burden of disease attributable to ambient air pollution: An analysis of data from the Global Burden of Diseases Study 2015. Lancet 2017, 389, 1907-1918. [CrossRef]

2. Yim, S.H.L.; Barrett, S.R.H. Public health impacts of combustion emissions in the United Kingdom. Environ. Sci. Technol. 2012, 46, 4291-4296. [CrossRef] [PubMed]

3. Wang, H.; Gao, Z.; Ren, J.; Liu, Y.; Chang, L.T.C.; Cheung, K.; Feng, Y.; Li, Y. An urban-rural and sex differences in cancer incidence and mortality and the relationship with PM2.5 exposure: An ecological study in the southeastern side of Hu line. Chemosphere 2019, 216, 766-773. [CrossRef]

4. Ackerman, A.S.; Toon, O.B.; Stevens, D.E.; Heymsfield, A.J.; Ramanathan, V.; Welton, E.J. Reduction of tropical cloudiness by soot. Science 2000, 288, 1042-1047. [CrossRef]

5. Guo, J.; Jiang, J.H.; Liu, H.; Jiang, M.; He, J.; Min, M.; Rosenfeld, D.; Li, Z.; Zhai, P.; Chen, D.; et al. Aerosol-Induced changes in the vertical structure of precipitation: A perspective of TRMM precipitation radar. Atmos. Chem. Phys. 2018, 18, 13329-13343. [CrossRef]

6. Lee, S.-S.; Ming, Y.; Qian, Y.; Xu, X.; Zhao, C.; Takemura, T.; Zhang, F.; Rosenfeld, D.; Li, Z.; Wang, K.; et al. Aerosol and monsoon climate interactions over Asia. Rev. Geophys. 2016, 54, 866-929.

7. Liu, H.; Wu, Y.; Wang, F.; Xie, T.; Lou, M.; Huang, J.; Guo, J.; Zhaxi, Y.; Yung, Y.L.; Jiang, J.H.; et al. Three-dimensional structure of aerosol in China: A perspective from multi-satellite observations. Atmos. Res. 2016, 178, 580-589.

8. Rosenfeld, D. Suppression of rain and snow by urban and industrial air pollution. Science 2000, 287, 1793-1796. [CrossRef]

9. Huang, J.; Guo, J.; Wang, F.; Liu, Z.; Jeong, M.J.; Yu, H.; Zhang, Z. CALIPSO inferred most probable heights of global dust and smoke layers. J. Geophys. Res. 2015, 120, 5085-5100. [CrossRef]

10. Liu, D.; Wang, Z.; Liu, Z.; Winker, D.; Trepte, C. A height resolved global view of dust aerosols from the first year CALIPSO lidar measurements. J. Geophys. Res. Atmos. 2008, 113. [CrossRef]

11. Qin, K.; Teng, J.; Hu, M.; Yuan, L.; Wu, L.; Lang, H.; Xiao, X.; Sheng, S.; Letu, H.; Wong, M.S. Trans-boundary aerosol transport during a winter haze episode in China revealed by ground-based Lidar and CALIPSO satellite. Atmos. Environ. 2016, 141, 20-29. [CrossRef]

12. Takemura, T.; Okamoto, H.; Maruyama, Y.; Numaguti, A.; Higurashi, A.; Nakajima, T. Global three-dimensional simulation of aerosol optical thickness distribution of various origins. J. Geophys. Res. Atmos. 2000, 105, 17853-17873. [CrossRef]

13. Miao, Y.; Guo, J.; Liu, S.; Liu, H.; Zhang, G.; Yan, Y.; He, J. Relay transport of aerosols to Beijing-Tianjin-Hebei region by multi-scale atmospheric circulations. Atmos. Environ. 2017, 165, 35-45. [CrossRef]

14. Randles, C.A.; da Silva, A.M.; Buchard, V.; Colarco, P.R.; Darmenov, A.; Govindaraju, R.; Smirnov, A.; Holben, B.; Ferrare, R.; Hair, J.; et al. The MERRA-2 aerosol reanalysis, 1980 onward. Part I: System description and data assimilation evaluation. J. Clim. 2017, 30, 6823-6850. [CrossRef] [PubMed]

15. Wainker, D.M.; Tackett, J.L.; Getzewich, B.J.; Liu, Z.; Vaughan, M.A.; Rogers, R.R. The global 3-D distribution of tropospheric aerosols as characterized by CALIOP. Atmos. Chem. Phys. 2013, 13, 3345-3361. [CrossRef]

16. Su, T.; Li, J.; Li, C.; Xiang, P.; Lau, A.K.H.; Guo, J.; Yang, D.; Miao, Y. An intercomparison of long-term planetary boundary layer heights retrieved from CALIPSO, ground-based lidar, and radiosonde measurements over Hong Kong. J. Geophys. Res. 2017, 122, 3929-3943. [CrossRef]

17. Samset, B.H.; Myhre, G.; Schulz, M.; Balkanski, Y.; Bauer, S.; Berntsen, T.K.; Bian, H.; Bellouin, N.; Diehl, T.; Easter, R.C.; et al. Black carbon vertical profiles strongly affect its radiative forcing uncertainty. Atmos. Chem. Phys. 2013, 13, 2423-2434. [CrossRef] 
18. Young, S.A.; Vaughan, M.A. The retrieval of profiles of particulate extinction from cloud-aerosol lidar infrared pathfinder satellite observations (CALIPSO) data: Algorithm description. J. Atmos. Ocean. Technol. 2009, 26, 1105-1119. [CrossRef]

19. Kacenelenbogen, M.; Vaughan, M.A.; Redemann, J.; Hoff, R.M.; Rogers, R.R.; Ferrare, R.A.; Russell, P.B.; Hostetler, C.A.; Hair, J.W.; Holben, B.N. An accuracy assessment of the CALIOP/CALIPSO version 2/version 3 daytime aerosol extinction product based on a detailed multi-sensor, multi-platform case study. Atmos. Chem. Phys. 2011, 11, 3981-4000. [CrossRef]

20. Omar, A.; Vaughan, M.A.; Young, S.A.; Hunt, W.H.; Liu, Z.; Powell, K.A.; Winker, D.M.; Hu, Y. Overview of the CALIPSO Mission and CALIOP Data Processing Algorithms. J. Atmos. Ocean. Technol. 2009, 26, 2310-2323.

21. Vaughan, M.A.; Powell, K.A.; Kuehn, R.E.; Young, S.A.; Winker, D.M.; Hostetler, C.A.; Hunt, W.H.; Liu, Z.; Mcgill, M.J.; Getzewich, B.J. Fully automated detection of cloud and aerosol layers in the CALIPSO lidar measurements. J. Atmos. Ocean. Technol. 2009, 26, 2034-2050. [CrossRef]

22. Burton, S.P.; Rogers, R.R.; Hostetler, C.A.; Vaughan, M.A.; Hair, J.W.; Omar, A.H.; Ferrare, R.A. Aerosol classification from airborne HSRL and comparisons with the CALIPSO vertical feature mask. Atmos. Meas. Tech. 2013, 6, 1397-1412. [CrossRef]

23. Oo, M.; Holz, R. Improving the CALIOP aerosol optical depth using combined MODIS-CALIOP observations and CALIOP integrated attenuated total color ratio. J. Geophys. Res. Atmos. 2011, 116. [CrossRef]

24. Pappalardo, G.; Wandinger, U.; Mona, L.; Hiebsch, A.; Mattis, I.; Amodeo, A.; Ansmann, A.; Seifert, P.; Linné, H.; Apituley, A.; et al. EARLINET correlative measurements for CALIPSO: First intercomparison results. J. Geophys. Res. Atmos. $2010,115$. [CrossRef]

25. Redemann, J.; Vaughan, M.A.; Zhang, Q.; Shinozuka, Y.; Russell, P.B.; Livingston, J.M.; Kacenelenbogen, M.; Remer, L.A. The comparison of MODIS-Aqua (C5) and CALIOP (V2 \& V3) aerosol optical depth. Atmos. Chem. Phys. 2012, 12, 3025-3043.

26. Schuster, G.L.; Vaughan, M.; MacDonnell, D.; Su, W.; Winker, D.; Dubovik, O.; Lapyonok, T.; Trepte, C. Comparison of CALIPSO aerosol optical depth retrievals to AERONET measurements, and a climatology for the lidar ratio of dust. Atmos. Chem. Phys. 2012, 12, 7431-7452. [CrossRef]

27. Omar, A.H.; Kar, J.; Powell, K.A.; Winker, D.M.; Vaughan, M.A.; Trepte, C.R.; Liu, Z.; Tackett, J.L.; Giles, D.M. CALIOP and AERONET aerosol optical depth comparisons: One size fits none. J. Geophys. Res. Atmos. 2013, 118, 4748-4766. [CrossRef]

28. Kim, M.H.; Kim, S.W.; Yoon, S.C.; Omar, A.H. Comparison of aerosol optical depth between CALIOP and MODIS-Aqua for CALIOP aerosol subtypes over the ocean. J. Geophys. Res. Atmos. 2013, 118, 13241-13252. [CrossRef]

29. Vaughan, M.A.; Kuehn, R.E.; Tackett, J.L.; Rogers, R.R.; Liu, Z.; Omar, A.; Getzewich, B.J.; Powell, K.A.; Hu, Y.; Young, S.A.; et al. Strategies for Improved CALIPSO Aerosol Optical Depth Estimates. In Proceedings of the 25th International Laser Radar Conference, Saint Petersburg, Russia, 5-9 July 2010.

30. Huang, L.; Jiang, J.H.; Tackett, J.L.; Su, H.; Fu, R. Seasonal and diurnal variations of aerosol extinction profile and type distribution from CALIPSO 5-year observations. J. Geophys. Res. Atmos. 2013, 118, 4572-4596. [CrossRef]

31. Gui, K.; Che, H.; Wang, Y.; Wang, H.; Zhang, L.; Sun, T.; Zhang, X.; Zheng, Y. Satellite-derived PM2.5 concentration trends over Eastern China from 1998 to 2016: Relationships to emissions and meteorological parameters. Environ. Pollut. 2019, 247, 1125-1133. [CrossRef] [PubMed]

32. Li, Z.; Guo, J.; Ding, A.; Liao, H.; Liu, J.; Sun, Y.; Wang, T.; Xue, H.; Zhang, H.; Zhu, B. Aerosol and boundary-layer interactions and impact on air quality. Natl. Sci. Rev. 2017, 4, 810-833. [CrossRef]

33. Yang, Y.; Zheng, X.; Gao, Z.; Wang, H.; Wang, T.; Li, Y.; Lau, G.N.C.; Yim, S.H.L. Long-Term Trends of Persistent Synoptic Circulation Events in Planetary Boundary Layer and Their Relationships with Haze Pollution in Winter Half Year Over Eastern China. J. Geophys. Res. Atmos. 2018, 123, 10991-11007. [CrossRef]

34. Yin, Z.; Wang, H. Role of atmospheric circulations in haze pollution in December 2016. Atmos. Chem. Phys. 2017, 17, 11673-11681. [CrossRef]

35. Zhang, R.H.; Li, Q.; Zhang, R.N. Meteorological conditions for the persistent severe fog and haze event over eastern China in January 2013. Sci. China Earth Sci. 2014, 57, 26-35.

36. Schwartz, C.S.; Liu, Z.; Lin, H.C.; Cetola, J.D. Assimilating aerosol observations with a "hybrid” variational-ensemble data assimilation system. J. Geophys. Res. 2014, 119, 4043-4069. [CrossRef]

37. Ma, C.; Wang, T.; Jiang, Z.; Wu, H.; Zhao, M.; Zhuang, B.; Li, S.; Xie, M.; Li, M.; Liu, J.; et al. Importance of Bias Correction in Data Assimilation of Multiple Observations Over Eastern China Using WRF-Chem/DART. J. Geophys. Res. Atmos. 2020, 125, e2019JD031465. [CrossRef]

38. Wang, F.; Guo, J.; Zhang, J.; Huang, J.; Min, M.; Chen, T.; Liu, H.; Deng, M.; Li, X. Multi-sensor quantification of aerosol-induced variability in warm clouds over eastern China. Atmos. Environ. 2015, 113, 1-9. [CrossRef]

39. Holben, B.N.; Eck, T.F.; Slutsker, I.; Tanré, D.; Buis, J.P.; Setzer, A.; Vermote, E.; Reagan, J.A.; Kaufman, Y.J.; Nakajima, T.; et al. AERONET-A federated instrument network and data archive for aerosol characterization. Remote Sens. Environ. 1998, 66, 1-16. [CrossRef]

40. Che, H.; Zhang, X.; Chen, H.; Damiri, B.; Goloub, P.; Li, Z.; Zhang, X.; Wei, Y.; Zhou, H.; Dong, F.; et al. Instrument calibration and aerosol optical depth validation of the China aerosol remote sensing network. J. Geophys. Res. Atmos. 2009, 114. [CrossRef]

41. Dubovik, O.; Smirnov, A.; Holben, B.N.; King, M.D.; Kaufman, Y.J.; Eck, T.F.; Slutsker, I. Accuracy assessments of aerosol optical properties retrieved from Aerosol Robotic Network (AERONET) Sun and sky radiance measurements. J. Geophys. Res. Atmos. 2000, 105, 9791-9806. [CrossRef] 
42. Jeong, M.J.; Li, Z.; Andrews, E.; Tsay, S.C. Effect of aerosol humidification on the column aerosol optical thickness over the Atmospheric Radiation Measurement Southern Great Plains site. J. Geophys. Res. Atmos. 2007, 112. [CrossRef]

43. Kaufman, Y.J.; Rudich, Y.; Koren, I.; Rosenfeld, D.; Remer, L.A. The effect of smoke, dust, and pollution aerosol on shallow cloud development over the Atlantic Ocean. Proc. Natl. Acad. Sci. USA 2005, 102, 11207-11212. [CrossRef]

44. Loeb, N.G.; Schuster, G.L. An observational study of the relationship between cloud, aerosol and meteorology in broken low-level cloud conditions. J. Geophys. Res. Atmos. 2008, 113. [CrossRef]

45. Young, S.A.; Vaughan, M.A.; Kuehn, R.E.; Winker, D.M. The retrieval of profiles of particulate extinction from Cloud-Aerosol Lidar and Infrared Pathfinder Satellite Observations (CALIPSO) data: Uncertainty and error sensitivity analyses. J. Atmos. Ocean. Technol. 2013, 30, 395-428. [CrossRef]

46. Hostetler, C.; Liu, Z.; Kittaka, C.; Getzewich, B.; Trepte, C.; Vaughan, M.; Winker, D.; Omar, A.; Kuehn, R.; Powell, K. The CALIPSO Lidar Cloud and Aerosol Discrimination: Version 2 Algorithm and Initial Assessment of Performance. J. Atmos. Ocean. Technol. 2009, 26, 1198-1213.

47. Young, S.A.; Liu, Z.; Hu, Y.; Omar, A.H.; Hostetler, C.A.; Vaughan, M.A.; Winker, D.M.; Powell, K.A. Fully automated analysis of space-based lidar data: An overview of the CALIPSO retrieval algorithms and data products. In Proceedings of the Laser Radar Techniques for Atmospheric Sensing, Maspalomas, Gran Canaria, Spain, 14-16 September 2004; Volume 5575, p. 16.

48. Kittaka, C.; Hu, Y.; Omar, A.H.; Ferrare, R.A.; Vaughan, M.A.; Winker, D.M.; Trepte, C.R.; Rogers, R.R.; Hostetler, C.A.; Lee, K.-P.; et al. The CALIPSO Automated Aerosol Classification and Lidar Ratio Selection Algorithm. J. Atmos. Ocean. Technol. 2009, 26, 1994-2014.

49. Toth, T.D.; Zhang, J.; Reid, J.S.; Vaughan, M.A. A bulk-mass-modeling-based method for retrieving particulate matter pollution using CALIOP observations. Atmos. Meas. Tech. 2019, 12, 1739-1754. [CrossRef]

50. Liu, M.; Lin, J.; Boersma, F.K.; Pinardi, G.; Wang, Y.; Chimot, J.; Wagner, T.; Xie, P.; Eskes, H.; Van Roozendael, M.; et al. Improved aerosol correction for OMI tropospheric NO2 retrieval over East Asia: Constraint from CALIOP aerosol vertical profile. Atmos. Meas. Tech. 2019, 12,1-21. [CrossRef]

51. Zhang, W.; Guo, J.; Miao, Y.; Liu, H.; Zhang, Y.; Li, Z.; Zhai, P. Planetary boundary layer height from CALIOP compared to radiosonde over China. Atmos. Chem. Phys. 2016, 16, 9951-9963. [CrossRef]

52. Huang, J.; Hsu, N.C.; Tsay, S.C.; Jeong, M.J.; Holben, B.N.; Berkoff, T.A.; Welton, E.J. Susceptibility of aerosol optical thickness retrievals to thin cirrus contamination during the BASE-ASIA campaign. J. Geophys. Res. Atmos. 2011, 116. [CrossRef]

53. Lee, J.; Hsu, N.C.; Bettenhausen, C.; Sayer, A.M. Retrieval of aerosol optical depth under thin cirrus from MODIS: Application to an ocean algorithm. J. Geophys. Res. Atmos. 2013, 118, 10111-10124. [CrossRef]

54. Che, H.; Gui, K.; Xia, X.; Wang, Y.; Holben, B.N.; Goloub, P.; Cuevas-Agulló, E.; Wang, H.; Zheng, Y.; Zhao, H.; et al. Large contribution of meteorological factors to inter-decadal changes in regional aerosol optical depth. Atmos. Chem. Phys. 2019, 19, 10497-10523. [CrossRef]

55. Remer, L.A.; Kaufman, Y.J.; Tanré, D.; Mattoo, S.; Chu, D.A.; Martins, J.V.; Li, R.R.; Ichoku, C.; Levy, R.C.; Kleidman, R.G.; et al. The MODIS aerosol algorithm, products, and validation. J. Atmos. Sci. 2005, 62, 947-973. [CrossRef]

56. Bilbao, J.; Román, R.; Yousif, C.; Mateos, D.; de Miguel, A. Total ozone column, water vapour and aerosol effects on erythemal and global solar irradiance in Marsaxlokk, Malta. Atmos. Environ. 2014, 99, 508-518. [CrossRef]

57. Guo, J.; Xia, F.; Zhang, Y.; Liu, H.; Li, J.; Lou, M.; He, J.; Yan, Y.; Wang, F.; Min, M.; et al. Impact of diurnal variability and meteorological factors on the PM2.5-AOD relationship: Implications for PM2.5 remote sensing. Environ. Pollut. 2017, 221, 94-104. [CrossRef]

58. Gui, K.; Che, H.; Chen, Q.; Zeng, Z.; Zheng, Y.; Long, Q.; Sun, T.; Liu, X.; Wang, Y.; Liao, T.; et al. Water vapor variation and the effect of aerosols in China. Atmos. Environ. 2017, 165, 322-335. [CrossRef]

59. Naeger, A.R.; Christopher, S.A.; Ferrare, R.; Liu, Z. A new technique using infrared satellite measurements to improve the accuracy of the calipso cloud-aerosol discrimination method. IEEE Trans. Geosci. Remote Sens. 2013, 51, 642-653. [CrossRef]

60. Groß, S.; Esselborn, M.; Weinzierl, B.; Wirth, M.; Fix, A.; Petzold, A. Aerosol classification by airborne high spectral resolution lidar observations. Atmos. Chem. Phys. 2013, 13, 2487-2505. [CrossRef]

61. Liew, S.C.; Welton, E.J.; Reid, J.S.; Campbell, J.R.; Giles, D.M.; Chew, B.N.; Salinas, S.V. Tropical cirrus cloud contamination in sun photometer data. Atmos. Environ. 2011, 45, 6724-6731.

62. Liu, B.; Ma, Y.; Gong, W.; Zhang, M.; Wang, W.; Shi, Y. Comparison of AOD from CALIPSO, MODIS, and Sun Photometer under Different Conditions over Central China. Sci. Rep. 2018, 8, 10066. [CrossRef] [PubMed]

63. Zhang, Z.; Zhang, M.; Bilal, M.; Su, B.; Zhang, C.; Guo, L. Comparison of MODIS- and CALIPSO-Derived Temporal Aerosol Optical Depth over Yellow River Basin (China) from 2007 to 2015. Earth Syst. Environ. 2020, 4, 535-550. [CrossRef]

64. Nelli, N.; Fissehaye, S.; Francis, D.; Fonseca, R.; Temimi, M.; Weston, M.; Abida, R.; Nesterov, O. Characteristics of Atmospheric Aerosols Over the UAE Inferred From CALIPSO and Sun Photometer Aerosol Optical Depth. Earth Sp. Sci. 2021, 8, e2020EA001360. [CrossRef]

65. Zhang, M.; Su, B.; Bilal, M.; Atique, L.; Usman, M.; Qiu, Z.; Ali, M.A.; Han, G. An investigation of vertically distributed aerosol optical properties over Pakistan using CALIPSO Satellite Data. Remote Sens. 2020, 12, 2183. [CrossRef]

66. Yang, Y.; Zheng, Z.; Yim, S.Y.L.; Roth, M.; Ren, G.; Gao, Z.; Wang, T.; Li, Q.; Shi, C.; Ning, G.; et al. PM2.5 Pollution Modulates Wintertime Urban Heat Island Intensity in the Beijing-Tianjin-Hebei Megalopolis, China. Geophys. Res. Lett. 2020, 47, e2019GL084288. [CrossRef] 
67. Zeng, Z.; Gui, K.; Wang, Z.; Luo, M.; Geng, H.; Ge, E.; An, J.; Song, X.; Ning, G.; Zhai, S.; et al. Estimating hourly surface PM2.5 concentrations across China from high-density meteorological observations by machine learning. Atmos. Res. 2021, $254,105516$. [CrossRef]

68. Yang, Y.; Fan, S.; Wang, L.; Gao, Z.; Zhang, Y.; Zou, H.; Miao, S.; Li, Y.; Huang, M.; Yim, S.H.L.; et al. Diurnal evolution of the wintertime boundary layer in urban beijing, china: Insights from doppler lidar and a 325-m meteorological tower. Remote Sens. 2020, 12, 3935. [CrossRef]

69. Chen, X.; de Leeuw, G.; Arola, A.; Liu, S.; Liu, Y.; Li, Z.; Zhang, K. Joint retrieval of the aerosol fine mode fraction and optical depth using MODIS spectral reflectance over northern and eastern China: Artificial neural network method. Remote Sens. Environ. 2020, 249, 112006. [CrossRef]

70. Che, H.; Xia, X.; Zhao, H.; Dubovik, O.; Holben, B.N.; Goloub, P.; Cuevas-Agulló, E.; Estelles, V.; Wang, Y.; Zhu, J.; et al. Spatial distribution of aerosol microphysical and optical properties and direct radiative effect from the China Aerosol Remote Sensing Network. Atmos. Chem. Phys. 2019, 19, 11843-11864. [CrossRef] 